\title{
THE INDIRECT INTENT IN THE INTERNATIONAL CRIMINAL CASE-LAW
}

\author{
Viorel PAȘCA, Bianca-Codruța BĂRA \\ West University Timișoara, Romania \\ viorel.pasca@e-uvt.ro,bara.bianca92@yahoo.com
}

\begin{abstract}
This study focuses on the analyse of the indirect intent in the international criminal caselaw. Traditionally, the Romanian Criminal Code defines the indirect intent through the pshychological position of the offender towards the result of the crime, which can lead, in some circumstances, to unfair result. Finding an appropriate definition has been a constant problem for the international courts of justice, especially taking into consideration the effort to reconcile this attempt with the national regulations and principles. The International Criminal Tribunal for Yugoslavia developed a new form of criminal participation in which it described the mens rea using the notion of 'risk'. The Tadic case represents a significant step for the definition of indirect intent, in the way it is considered in our legal system.The international criminal court emphasizes the importance of the person's position towards the risk that criminal acts could lead to relevant results and it outlines the standards of foreseeability of such risk.
\end{abstract}

\section{Keywords: indirect intent, risk, joint criminal enterprise, result, mens rea}

\section{Introduction}

Two important elements have to be established regarding the criminal liability. On the one hand, it has to be determined if there is an action or omission (actus reus) and, on the other hand, if there was a specific psychological process of the wrongdoer that led to the comission of the crime (mens rea).

The Romanian Criminal Code identifies a number of five forms of guilt: the direct intention, the indirect intention (also known as dolus eventualis), recklessness, negligence and praterintention [1].

The Romanian legislator defines these forms of guilt through the psychological process of the wrongdoers towards the possibility that a specific result may occure. Establishing the criminal liability only in regard of the psychological position of a wrongdoer towards a result can lead to an extremely unfair interpretation.
The criminal activity is a progressive process which evolves in time and space. Until the the final moment when the harm is done (the occurance of the result), the iter criminis (meaning the criminal process) goes through several stages [2]. In fact, this is the reason why criminal law regulates and punishes the attempt of committing a crime.

Establishing the criminal liability implies a rigorous analysis of all the consequences that the actions or omissions of a person generate[3]. Therefore, beside the final result of a crime, criminal law has to take into consideration the risk that specific human conducts create towards the social values protected by the law.

\section{The international criminal case-law}

The international criminal law deals with crimes of a wide geographical, economical and political sphere. The transnationality and the special dimensions of these crimes 
raise extremely complex legal issues regarding the criminal participation and the mens rea.

The important challenge of the international criminal law was the criminal responsibility of those who co-ordinated and conducted crimes against humanity or war crimes, persons that constituted the triggering force of the criminal activities, as against to those who had only executed the criminal plan.

Another important issue was the criminal liability of these war leaders for the crimes committed by their subordinates besides the common criminal purpose. The international crimes are committed by a large criminal group who act according to a specific aim. In order to reach this purpose, the criminal group establishes a common plan. The delicat problem arises when a member of this group commits a crime besides this common plan, without having it discussed with the entire group but committing this crime is a mere form of achieving the criminal joint purpose [4].

For reasons of fairness, international criminal courts gave legal value to the position that the war leaders adopt against the risk of producing critically results, results that they do not always program but foresee up to a certain point.

The adoption of traditional principals and rules from the national legal systems for the resolution of these legal problems would have led to unfair results, considering the specificities of these criminal cases.

The international criminal courts have borrowed the notion of risk in the construction of guilt, especially with regard to the indirect intention, where we find the notion of "a willingly taken risk".

Prosecutor vs. Duško Tadić, a case brought before the International Criminal Tribunal for the former Yugoslavia (hereinafter I.C.T.Y.) is the reference case in which it was raised the question of a new form of criminal participation and the notion of "a willingly taken risk.
Duško Tadić was a regional leader of the Serbian nationalist party S.D.S. from Bosnia Herzegovina, being an outstanding participant in the formation plan of the 'Big Serbia'. The aim of this plan was the ethnic cleansing of the Prajedor region by eliminating the Croatian and Muslim population. Duško Tadić contributed to the establishment of a regime of terror against the Croatian and Muslim population, a regime that led to the killing, rape and the battering of many civilians [5].

The Trial Chamber acquitted Tadić for killing the 5 civilians in the village of Jaskići. According to the court, his participation in these crimes did not equate to the to direct perpetration, nor he was he liable under the theory of superior responsibility [6].

The Appeals Chamber of the I.C.T.Y. changes this solution using a so-called theory of customary international law` [7]. In order to establish Duško Tadić's criminal liability, the I.C.T.Y. creates a new form of criminal participation called the 'joint criminal enterprise' (a common purpose liability), composed of three distinct categories of collective criminality, which have come to be known as Joint Criminal Enterprise (JCE) I, II and III [8].

The third type of the joint criminal enterprise is the one that is important for analyzing the implications of risk in the criminal law.

The third category of joint criminal enterprise' (extended joint enterprise) is characterized by at least two participants, the existence of a common criminal plan and the committing by one of the participants of an offense not forming part of that joint plan, but which is a means of the materialization of the original objective [9].

From the mens rea's point of view, 'what is required is the intention to participate in and further the criminal activity or the criminal purpose of a group and to contribute to the joint criminal enterprise or in any event to the commission of a crime by the group. In addition, responsibility for 
a crime other than the one agreed upon in the common plan arises only if, under the circumstances of the case, it was foreseeable that such a crime might be perpetrated by one or other members of the group and the accused willingly took that risk' $[10]$.

In the Tadic case the joint criminal enterprise is represented by an armed group. The common plan of this group is the ethnic purification of the Prajedor region. Although Tadic did not directly execute the material acts of murders that were not included in the initial plan, he was able to predict the possibility of these results occurring, voluntarily assuming this risk.

In the appeal decision, the I.C.T.Y. defines the two major elements that characterize the mens rea in the case of J.C.E. III:

a) the intention to participate and contribute to the achievement of the joint purpose of the group;

b) the possibility to foresee that other members of the group will commit offenses other than those strictly related to the original plan but which have an important link with the latter, a risk that the person willingly takes [11].

According to the court, the psychological state of mind in which a person, although not seeking to bring about a specific result (other than the one contained in the criminal joint plan, such as the 'ethnic cleansing"'pursued by Duško Tadić), foresees that the actions of the group were most likely to lead to that result but nevertheless willingly took that risk, takes the form of a dolus eventualis or an advertent recklessness [12].

The way that dolus eventualis is understoond by the I.C.T.Y. is close to the definition that the Model Penal Code gives to recklessness: ' a person acts recklessly with respect to a material element of an offense when he consciously disregards a substantial and unjustifiable risk that the material element exists or will result from his conduct. The risk must be of such a nature and degree that, considering the nature and purpose of the actor's conduct and the circumstances known to him, its disregard involves a gross deviation from the standard of conduct that a law-abiding person would observe in the actor's situation' [13].

In the Romanian criminal law the definition that the I.C.T.Y. gives to dolus eventualis characterizes the indirect intent. The main difference betwen the indirect intent and recklessness relies on the fact that in the first case the offender foresees the risk and accepts the posibility of it to happen (although he doesn not have the intent to achieve this result), while in the second case, the wrongdoer foresees the risk but unjustifiably believes that the result will not become a result forbbiden by the criminal law [14].

The theory of the joint common enterprise has substantiated the criminal responsibility of important criminal group/organization leaders in other resounding cases brought before the international criminal courts. These courts have continued with the I.C.T.Y. perspective towards indirect intent, in the way it was established in the Tadic case.

An important trial brought before the I.C.T.Y. was that of the Serbian General Radislav Krstić, the commander of the Drina Army Corps, whose troops were actively involved in the Srebrenica massacre in 1995 [15].

Together with the officers of the Army General Staff of the Republic of Srpska and the State Major of CA Drina, Radislav Krstić was a key element in the forced deportation of the Muslim women, children and the elderly who lived in the city of Srebrenica [16].

Radislav Krstić was found guity for several crimes of murder, rape and battering. The I.C.T.Y. rulled that these crimes were a natural and predictable consequence of the deportation plan of the Muslim population, even though they were not established together with the common plan [17]. 
In defining the mens rea of Radislav Krstić, the I.C.T.Y. interpreted the Tadić Appeal Judgement as follows:.

If the crime charged fell within the object of the joint criminal enterprise, the prosecution must establish that the accused shared with the person who personally perpetrated the crime the state of mind required for that crime. If the crime charged went beyond the object of the joint criminal enterprise, the prosecution needs to establish only that the accused was aware that the further crime was a possible consequence in the execution of that enterprise and that, with that awareness, he participated in that enterprise.' [18].

Another case in which this theory was applied was the Édouard Karamera Case [19], brought before the International Criminal Tribunal for Rwanda (hereinafter I.C.T.R.).

Édouard Karamera was a former minister of the Interim Government of Rwanda who actively participated in the extermination of the Tutsi population of Rwanda.

He was convicted of genocide complicity, direct and public incitement to genocide, genocide, crimes against humanity (rape), crimes against humanity (extermination), serious violation of article 3 of the Geneva Convention and the provisions of Additional Protocol II [19].

The defense argued that the offenses that were not part of the initial plan can only be predictable if the joint criminal enterprise has a very clear purpose, with precise coordinates in time and space.

The defendant argued that his criminal liability for rapes, murders and other crimes against the Tutsi population can not be justified, precisely because of the impressive extent of these crimes in Ruanda. As a consequence of that, the risk of these crimes could not be a natural and foreseeable consequence of the execution of the joint plan [20].

The Trial Chamber, referring to previous case law [21], pointed out that the joint criminal enterprise does not only apply to criminal plans that have a limited scope but can also serve to achieve a broader objective [22].

In order to be able to determine the predictability of the risk, the court ruled that it is necessary to establish what were the concrete information that the defendant had about the situation [23].

In this case, the hierarchical position of the defendant, as well as the important meetings he attended, enabled him to obtain sufficient information regarding the risk of rape of the Tutsi women, for example. Therefore, these crimes were 'a natural and predictable consequence' [24] of the general ethnic cleansing purpose.

\section{Conclusions}

Using the notion of risk in the construction of the indirect intent (recklessness in the international criminal courts' view) represented a great opportunity for establishing the criminal liability of the liders of criminal groups in complex cases such as those that have been previously presented.

The necessity of this new perspective towards the forms of guilt arise from the absence of any rules regulating this type of criminal participation in the Statute of I.C.T.Y but also from the existence of the classic principles of criminal liability.

The only form of criminal liability that is similar to a criminal collective responsibility would be aiding and abetting. However, criminal liability for aiding and abetting is considerably lower than the one established by the international criminal courts in the cases presented above, which raises a matter of equity [25].

\section{References}

[1] Article 16 from the Romanian Criminal Code.

[2] V. Pașca, Drept penal. Parte generală (Criminal Law. The general part), ediția a IV-a revizuită și adăugită, Universul Juridic, București, 2015, p. 246. 
[3] V. Dongoroz ș.a., Explicaţii teoretice ale Codului penal român (The theoretical explanations of the Romanian Criminal Code), vol. I, Editura Academiei Republicii Socialiste România, București, 1969, p. 109.

[4] M. A. Summers, Mark A. Summers, Washington University Global Studies Law Review, Volume 13, 2014, p. 667-668.

[5] Prosecutor v. Duško Tadić, nr. IT-94-1-T, 14th of July 1997, par. 127-179.

[6] M. A. Summers, op.cit., p. 672.

[7] Prosecutor v. Duško Tadić, nr. IT-94-1-A, 15th of July, par. 194-195.

[8] Idem, par. 195.

[9] Prosecutor v. Duško Tadić, nr. IT-94-1-A, 15th of July 1999, par. 204.

[10] Idem, par. 228.

[11] Idem, par. 220.

[12] Prosecutor v. Duško Tadić, nr. IT-94-1-A, 15th of July 1999, par. 220.

[13] Model Penal Code, section 2.02. General Requirements of Culpability.

[14] M. Udroiu, Drept penal. Parte Generală (Criminal Law. The general part), Editura C.H.Beck, București, 2014, p. 54.

[15] L.-A. Lascu, Modalități de participare la comiterea crimelor date în competenţa instanțelor penale internationale (Ways to participate in the commission of the crimes under the jurisdiction of the international criminal court), Editura Hamangiu, București, 2013, p. 146.

[16] Prosecutor v. Radislav Krstić nr. IT-98-33-T, 2nd of August 2001, par. 615.

[17] Idem, par. 616.

[18] Idem, par. 613.

[19] Prosecutor v. Cauza Édouard Karamera, nr. ICTR-98-44-T, 2nd of February 2012.

[20] Prosecutor v. Édouard Karamera, nr. ICTR-98-44-A, 29th of September 2014, par. 137.

[21] Prosecutor v. Radislav Brdanin,nr. IT-99-36-A, 3rd of April 2007, par. 420-425.

[22] Prosecutor v. Cauza Édouard Karamera, nr. ICTR-98-44-T, 2nd of February 2012, par. 1435.

[23] Ibidem.

[24] Idem, par. 628.

[25] M. A. Summers, op.cit., pp. 668-669. 